\title{
A HISTOCHEMICAL STUDY ON THE INFLAMMED PALATINE TONSILS
}

\author{
By
}

H. TANAKA

\author{
From the First Pathological Institute, Faculty of Medicine, Hirosaki University \\ (Director: Prof. K. Sato) \\ and
}

From the Department of Oto-Rhino-Laryngology, Akita Prefectural Central Hospital

(Chief: S. Maekawa)

The author made histological and histochemical examinations on 113 tonsils obtained from 60 patients, and obtained following results.

Glycogen and fat content, result of pyronin staining and localisation of the mast cells in the tissues were found to be in connection with the length of time after the acute inflammatory signs thad clinically subsided, PAS-stain, mucicarmin-stain, amyloid degeneration and the hemosiderin deposit seemed not to be in close relation with the length of time after the inflammation.

\section{炎症性口蓋扁桃の組織化学的研究}

\section{弘前大学医学部第 1 苪理学教室（指導：传藤光永教授）

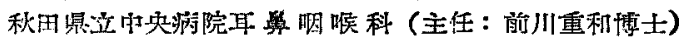

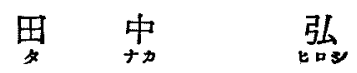

目次
筑】章緒言
一管 II章 研究材粗並でに研究方法

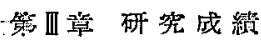

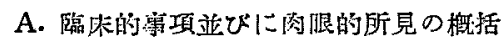
B. 病理組織学的一般所見
C. 組織化学的所見

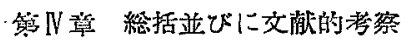

䈍V算 結 論

$$
\text { 主要交能 }
$$

\section{第I章 緒言}

口蓋扁桃炎は最も普辺的な疾病の一つであり, 病巣感 染等の観点からは問題の多いもの১一つである.それで 口蓋扁桃に関する研究は，従来各方面より行われて和 り，最近に至り生化学的あるいは組儎化学的研究も行わ れるよらになつたが，研究の余地は牫されている。

私は炎症時に拉ける物望代謝を研究する目的で，炎症 性口盖扇桃の臨床的並びに因眼的観察を行い，更に組織 化学的噈究を行つたので報告する.

\section{第II 立 研究材料並びに研究方法}

材料は秋田県立中央病院耳鼻科において手術的に得た
60 例 (切除例 6, 摘出例 54)，113 個 (1 側例 7, 両側例 53）の人口蓋扁桃で，その臨床診断を表 1 , 症例の急性 炎症症状消很後手術施行迄の期間（以下経過日数々記 す)・酶本の側別・数等を表 2 , 年令別・性別は表 3 に示 した。

表 1 枋料の臨床診 断による分穎

\begin{tabular}{|c|c|}
\hline 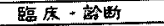 & 例数 \\
\hline 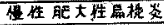 & 10 \\
\hline 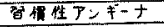 & 47 \\
\hline 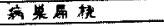 & 3 \\
\hline 柿 & 60 \\
\hline
\end{tabular}

表 2 標本数及どその週別・ 側別

\begin{tabular}{|c|c|c|c|c|c|}
\hline \multicolumn{2}{|c|}{ 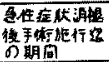 } & \multicolumn{2}{|c|}{ 倒 别 } & \multicolumn{2}{|c|}{ 鼓 } \\
\hline 群 & 週 & 右倒 & 厌恻 & 揑数 & 例做 \\
\hline $\bar{A}$ & $0 \sim 1$ & 2 & 3 & 5 & 3 \\
\hline B & $1 \sim 2$ & 3 & 3 & 6 & 4 \\
\hline$c^{c}$ & $2-3$ & 7. & 8 & 15 & 8 \\
\hline D & $3 \sim 4$ & 5 & 4 & 9 & 5 \\
\hline$E$ & $4 \sim 8$ & 15 & 15 & 30 & 15 \\
\hline$F$ & $8 \sim$ & 23 & 25 & 48 & 25 \\
\hline & 新 & 55 & 58 & 113 & 60 \\
\hline
\end{tabular}

手術拖行に先立ら，病歴・臨床所見を詳細に検查し た・シ手術はできる限り組織の損壊を避け，鉗子等で把持 する事を慎んだ・術後直ちに肉眼的観察・計测・計量を 行い，これを上・下極を結ぶ垂直線上で，且つ遊離表面 及び被膜を含んで2 分し，10\%ホルマリン及び純アルコ 一ルで固定した。手術適応の関係上，急性最燃期のすの 
表3 林料の年令别 - 年別

\begin{tabular}{|c|c|c|c|}
\hline 年A & 男 & 女 & 計 \\
\hline $0 \sim 10$ & 8 & 2 & 10 \\
\hline $11 \sim 15$ & 9 & 5 & 14 \\
\hline $10 \sim 20$ & 12 & 9 & 21 \\
\hline $21 \sim 30$ & 5 & 4 & 9 \\
\hline $31 \sim 40$ & 3 & & 3 \\
\hline $41 \sim 50$ & 3 & & 3 \\
\hline 計 & 40 & 20 & 60 \\
\hline
\end{tabular}

は材料とし得ず，臨床上急 性炎症タ状の消裉してから のものが対象となつたので あるが，経過日数を表 2 の 如く6 群に分類し，主とし て䔃織!化学的所見と経過日 数との関係を見た・標本は 固定約 1 カ月後, 普通パラ フイン包埋で $7 \mu$ の切片及び $20 〜 30 \mu$ の東結切片を半 截面住平行した面で作製した・施行した染色法は次の如 くである.

1) Hämatoxylin-Eosin 染色法 (H-E)

2) van-Gieson 氏染色法 ( $v-G$ )

3) Sudan III (S. II) を用いる脂肪染色 (Daddi 氏 法)

4) Sudan Black B (S.B.B.)を用いる脂肪染色 (Lison 氏法)

5) 過沃菜酸 -Schiff 氏反応 (PAS反応, Mc. Manus 氏法) 及びこ礼々 $1 \%$ Diastase 消化試堬の併用

6) Mayer 氏 Mucicarmin 染色法

7) Amyloid 染色法 (Bennhold 氏法)

8) Pyronin-Methylgreen に上る核酸染色 (Brachet 氏法)

9) Toluidin-Blue による Metachromasie 染色 (岡 本・門田・青山氏法)

10) Berliner Blau 反応 (Perls-Stieda E法)

\section{第 III 章 研究成績}

A. 臨床的事項並びに肉腿的所見の概括

1) 60 例を年階別に見ると，10才以下は少なく，それ らの多くは肥大症例で，突隆型を示す。また，10才代 で最も多発し，埋没型は遂年增加の傾向を見る．高年者 で怯習情性高度者のが手術の対象之なつている。

2）既往に虫垂炎を経過する者が $12 \%$ ，家族の中に虫 垂炎経過者を有する者 $22 \%$ である。

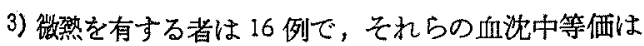
10,1 $1 \mathrm{~mm}$ であつた.

4) 大きさと重量は個人差が薯しいが，扁摘例では平 均 $4,6 \mathrm{gr}$. 最大重量 $9,0 \mathrm{gr}$. で，扁切例では平均 $2,5 \mathrm{gr}$. であった.

5) 腺窝数を扁摘例で見ると. 肉眼的には 4 28 個で, 气の左均は 10，9.個である。腺窟数は左右で多少の差を 有するが, 著差がない。

6) 腺篬内栓子形成は 41 側，36\%に認められたが，
これは経過日数 1〜2 週には少なく，それ以後は $40 \%$ 位 の頻度に見られた。またこれの存在と扁桃の形状との 間には特記すべき関係は認好難たかつた。

B. 病理組織学的一般所見

H.E p v-G 染色標本により 検索した成續を表 4 に 示めし，これに従つて説明を加える.

表 4 一般組織所見 (H.E,v-G. 染色)

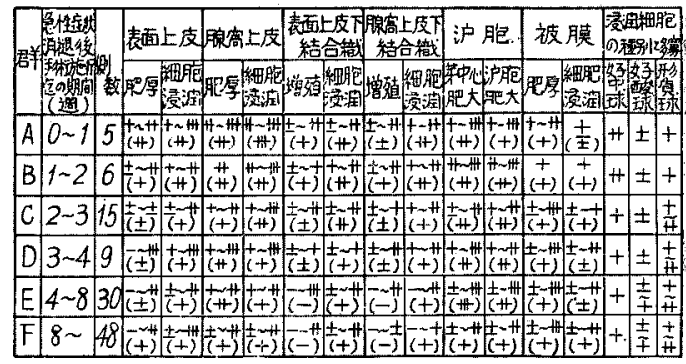

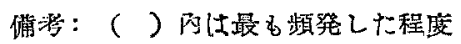

1）表面上皮：経過日数と比較的無関倸に軽度〜中等 度〜高度の肥厚状態を示し, 細胞浸潤の程度む区なであ るが,一般に軽衤である。

2）腺窩上皮：急性炎症消裉後初期泣は後期に比し， 肥厚程度が大である・細胞浸潤も同様に初期に高度な傾 向がうが゙われる。

3）表面上皮下結合織：一般に增殖度は不定である が，経過日数が大なる程 (4 週〜群)，堌殖を認めない例 が存する. 細胞浸潤も種々の程受に見られるが, 0 3 週 群に著しい。

4）腺䑪上皮下結合織：腺窝を囲綂する結合織は腺简 入口部を除いては著明には認め難いが，その增殖度はほ ぼ表面上皮下結合織のそえと平行している。細胞浸潤は 前者より遥かに高度で，特に0〜2週群で著明であり，2 週〜群では次第に程度は少なくなるが，かなりの浸潤細 胞を認める。

5）濾胞：芽中心肥大は $0 〜 4$ 週群の殆ど全例に認め， 4 週〜群でも半数以上に認める. 濾胞の肥大る前者とほ ぼ平行するもの小如くである。

6) 被膜：肥厚度については，特記すべき事はない が，細胞浸潤は1〜3 週群でや〉增強の傾向を标してい る.

7) 浸潤細胞の種別とその多算：極く早期（０２週， 群)、には好中球がや〉多いが，一般记好中球浸潤は少な い. 好酸球及び形質球は後斯群仁多数認めら九，年の浸 潤程度は概ね平行する。但しピロニン染色で形質球が好- 
に酸球よりむより多く，より容易に認められる。

8) なお，表には記入していないが，多くの例で腺䈧 上皮の一部崩壊せる像を認め，腺窝腔には脱落上皮・淋

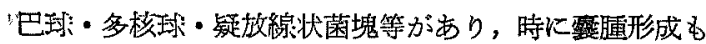
、認められた・

C. 組䋨化学的所見

1) 粘液多糖類 (PAS 反応) (表 5)

i）上皮組織：表面上没の表層，特に角化曆は全例強 "陽性を沶し，梁層特に基底層では染色性が弱い:これは

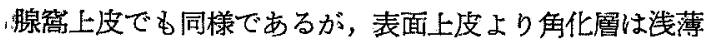

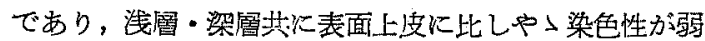
以. 従つて腺氼入口部は，両者の移行型とむ云うべく， 比較的澧染する.

表 5 PAS 反応 (グリコーゲン)

\begin{tabular}{|c|c|c|c|c|c|c|c|}
\hline & 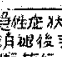 & 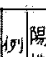 & & 芚組批独 & & 胞 & 結合䄑 \\
\hline & 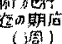 & 性 & & 腺窗 & H中心 & 觔 & 伯筫被朕 \\
\hline A & $0-1$ & \pm & & & & & $f(1)$ \\
\hline & & 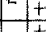 & $2(2)$ & $2(2)$ & $1(1)$ & & $1(1)|2(2)|$ \\
\hline B & $1-2$ & $3 \longdiv { 1 } +$ & $3(3)$ & $3(3)$ & & & $\frac{1(2)}{2(1)}$ \\
\hline $\mathrm{C}$ & $2-3$ & $7 \pm$ & (3) & $(3)$ & $1(1)$ & & (3) (4) \\
\hline & & + & $7(4)$ & $7(4)$ & & & \begin{tabular}{ll|l}
$7(4)$ & $7(3)$ \\
\end{tabular} \\
\hline D & $3-4$ & $5 \pm$ & $\frac{(2)}{5(3)}$ & $\mid \begin{array}{r}12 \\
5(3)\end{array}$ & & & \begin{tabular}{|r|r|}
$(2)$ & $(3)$ \\
$5(3)$ & $5(2)$ \\
\end{tabular} \\
\hline$E$ & & $5 \pm$ & $(3)$ & $\mid(3)$ & $1(1)$ & & (5) 13 \\
\hline & & $3 \pm$ & (4) & (5) & 212 & 10 & \begin{tabular}{|l|l|}
$3(8)$ & $(6)$ \\
\end{tabular} \\
\hline & & & $3(199$ & $\sqrt{236}$ & & & $20(15) 22(16)$ \\
\hline
\end{tabular}

備㘼：（）阿数字圄消化試験後のもの

ii）濾胞：芽中心部においては，55 例中７.例に軽度 陽性を認めたが，濾胞周辺部では 1 例の軽度陽性を認め たに過ぎない，経過日数との関係は明らかでなく，陽性 例は全群に撒布されている。

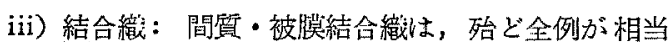
高度に染色される。

2) グリコーゲン（PAS 反応と消化試伢）

PAS 陽性物質がグリコーゲンであるか否かを磁かめ るために，PAS 染色醥本と，1\%ヂアスタ一ゼ溶液で $37^{\circ} \mathrm{C}, 1$ 時間処理した後に，PAS 染色它行つた 瞟本を 対比し，染色性が低下している場合に，消仁試験陽性即 らグリコーゲンの含有しているものとした

消化試鈳によれば，表 5 に見る如く，上皮組䋨では2 週〜䩴に軽度陽性，即らグリコーゲンの少量の存在を示 し，濾胞部では全例が陰性，結合䅄では $1 / 3$ 珵度の例に 少量のダリコーゲンの存在を現わしこれは0〜3週群 が3〜8週〜群より強い.

3) 粘液染色（表6）
摘出票本中，便宜上粘液腺が見られたるの11 例，見 られないるの 14 例, 計 25 例について検索した。

明らかに强染するのは粘液腺細胞・腺腟及び導管内容 のみである・表面上皮・腺窩上皮・結合䌦は約半数が弱 染する・これらと粘夜腺の有無や経過日数との関係は特 に認められない。

表 6 战液 (Mayer 氏ムテカルミン染色)

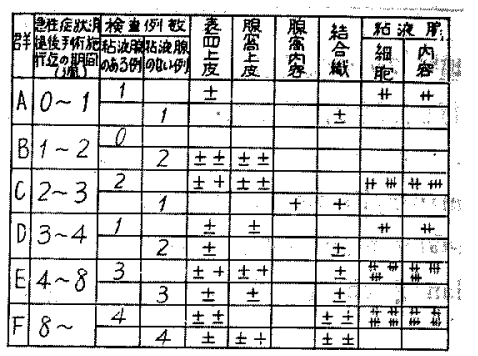

4) アミロイげ(表 7$)$

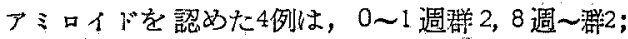
男 2 ，女 2 ；年令的に 8〜25才の むのである. 認められ た部位は中隔結合较 4，血管壁 3 ; 被膜 1 で，第 2 ・第 例では，変泩は中隔結合絓々続く㴓胞周囲の細網線維に も起つていた。

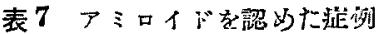

\begin{tabular}{|c|c|c|c|c|c|c|c|c|}
\hline & 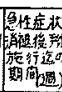 & & & 经 & 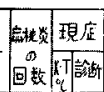 & 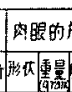 & $\mathbf{s}$ & 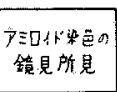 \\
\hline & $0 \sim 1$ & $A$ & & 5 & & 28 & & 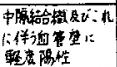 \\
\hline & & & & 3 肺炎 & & 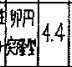 & & 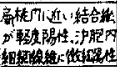 \\
\hline & $8 \sim$ & & 8 & 显疹 & 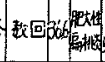 & 4 & & 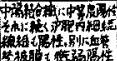 \\
\hline & & & & 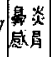 & & & & 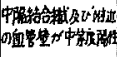 \\
\hline
\end{tabular}

これらの4 例は臨床的には，既往憷に特記事項なく， 扁桃炎は数回乃至十数回経過している.また，第 1 ・篦 2 例では微熱を有していた。因腿的には4 例共に突隆型 を示し，重量や瘉着度は区なで，組䋨学的一般所見す他 の症例と大して差異を認めない.

5）核酸 (ピロニン陽性度)（表 8)

i）上皮組縭：袁面上皮浅層は各群共に強陽性を示し， 梁層は軽度〜中等度陽性を示しているが，各群共相当幅 のある染色性を沶す．浸潤細胞中の陽性細胞数も各群に より相当幅がある。腺窩上皮においてす浅層は梁層に比 し好染するが，各䍩間の著明な差異は認めない。しか 
し，表面上发よりかなり多数の好染細胞の遊出がある。

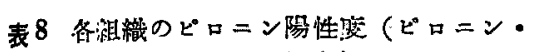
メシールグシーン染色）

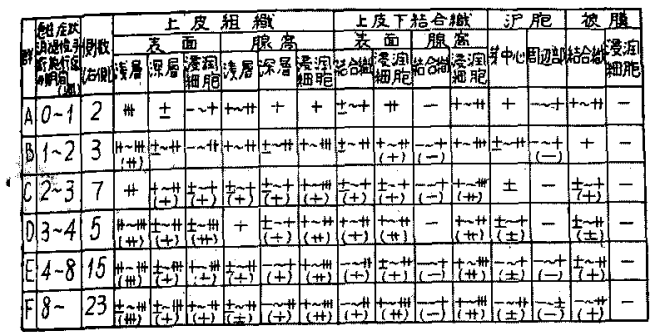

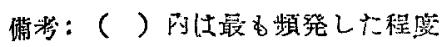

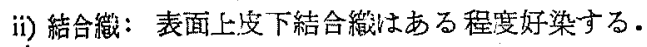
腚管上皮下結合繶では，腺窝入口部以外は著明でない。

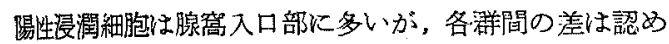

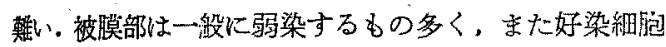
は殆と認めない。

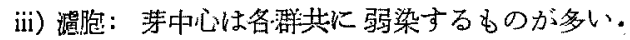
周边部は一般に陰性で，時に好染細胞を見る。謔胞にお ける陽性度は各涪で著明な差はない。

6) 脂 貿

S.【, S.B.B.の 2 染色法を行い，その長短を埋め合せ 犬. S. II て処理すれば，脂質は橙色乃至赤橙色を呈し， S.B.B. では，暗藍色万至黒色に染色されるが， S. IIIK よる陽性判定は，S.B.B.の場合よりや入概略的であり， 殊见軽度陽性の判定に困惑する場合があつたーしかし， 凡その傾向を和るには，S. II の方が半定容易のため， 却つて都合がよいので，主としてこの染色法に上る所見 を述べる事化し，S.B.B. の所見は判定に際する補助亡 lた.

\section{i) 公部位の脂筫の分布}

いつ机の部分にも脂質を認めるが，各部位によつてそ の晹性度を異にする。

（a）上皮租䋨：上支組艟でこれを明らかに検出する 事标稀で，またその陽性度は低い，表面上这では腺䈑上 皮上りも陽性度が高く，梁䁲上りは浅層に强く出る傾向 がみられた。

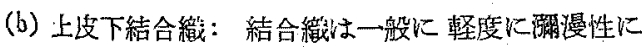
S.【Iの色譯を帯びるが，陽性と判定したものは表面に

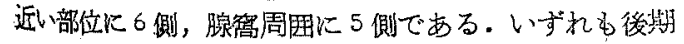
Кみられた。

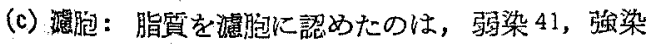
15 計 56 側で，その中，茅中心飞認めたもの 17 側, 周
辺部に認めたものは39 側である・これらは点状あるい は稀漫性に存在する。

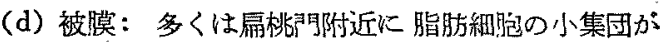
点在し，また被膜の結合繳が弱染する場合がある. 被膜 部は他の部位と比較すれば，最も脂筫が多量に存在す る.

以上の検查対象は60 側，113個であるが，唱質を証 明したものを策計すれば，47 例 $(78,3 \%) ， 70$ 側 $(61,9$ \%)で，その中 20 側は土程度である。

ii) 年令的分布

年膄的にみると，脂舅は16〜30才代に多く，次いで 31〜50才代，11〜15 才代で，10才以下ではや〉陽性率 が低い.

iii）経過日数と脂貿の分有

表 9 亿示した如く，陽性率 (側数)は，S. II では，0 〜 週群で $80 \%, 1 \sim 2$ 週渠で 66,6\%,2〜3 週群で 40\%， $3 \sim 4$ 週群で 66,6\%，4 8 週锌で 60\%，8 週〜群で 66, 6 \%で，0〜1 週群にかなり多いが，0〜2 週諳は例数が少 ないので 結論的な事は云えない。2〜3週群の陽牲率は

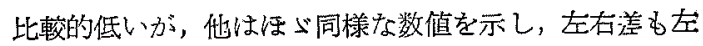
程でない。しかし，量は後半に多くなる傾向が汉られ た.

表 9 脂筧の分有 (S. II 染伯)

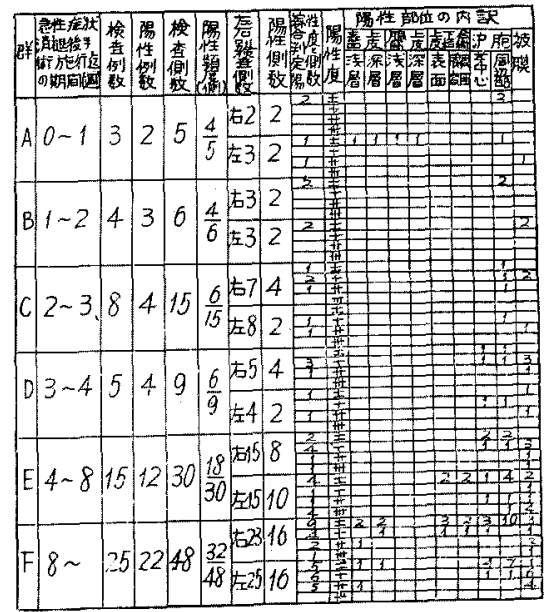

7) メタタロマジー

トルイジン青を用いてメタクロマジーを見，組織肥㭌 細胞を観察した。

一般に人口蓋扁㯇では鏡下に認める本細咆の数は多く なく，表10の如く，上皮組織汇は少なく，結合織成分 
殊に被膜一瀜桃門附近に多く，濾胞では周辺部に多い。 本染色法によれば殆ど凡ての標本に本細胞を観察する事 ができるが，その実数は余り多くなく，また，経過日数 との関係をみ叔ば，後半期には少なくなつている。

表 10 組織肥㭌䇆胞の分布

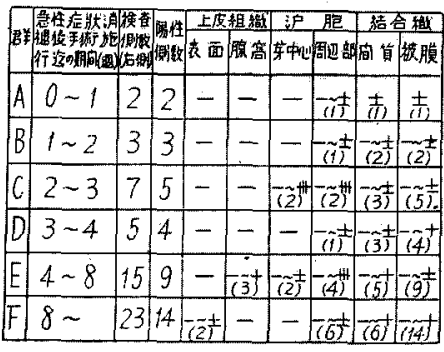

7) 鉄

Perls-Stieda 氏法によりへモジデリンを検出した。 なお，本標本作製のため，切片等の取钑いに鉄製針は避 け，竹製品を使用した。

55 例中 21 例では，いずれかの部分に鉄を認めたが， 濾胞殊にその周辺部に比較的多く見られた．群別には䈐 差がない。

萃 11 組繶鉄（ベルリン得反応）

\begin{tabular}{|c|c|c|c|c|c|c|c|c|}
\hline 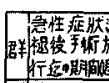 & & & & & & & & \\
\hline$A 0 \sim 1$ & 2 & 1 & - & & $\tilde{(\tau)}$ & - & - & - \\
\hline \begin{tabular}{|l|l}
$B$ & $1 \sim 2$
\end{tabular} & 3 & 2 & $\rightarrow+(i)$ & $\overline{i j}$ & $-\tau^{t} t$ & $\tilde{7}$ & - & $-{ }_{n i}$ \\
\hline $2-3$ & 7 & 4 & $-i z$ & - & - & (15) & (2) & -7 \\
\hline \begin{tabular}{l|l} 
D $3-4$ \\
\end{tabular} & 5 & 1 & - & - & - & - & $-\pi^{-1}$ & $1-$ \\
\hline E $4 \sim 8$ & 15 & 1 & - & - & $-i t$ & - & - & - \\
\hline F $8 \sim$ & & & & & & & (2) & - \\
\hline
\end{tabular}

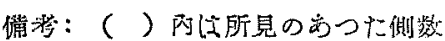

\section{第 IV 章 総括並びに文献的考察}

人口蓝扁桃の研究は組織学的にも病理学的 1) 2)5ｋ る数多くの研究があるが，近年漸次組繶化学学的方面の 研究も盛えとなつた。次に私の研究と関係ある報告を取 りあげて教察してみる.

1. PAS 陽性物質並びにグリコーゲンに関して グリューゲンの組䋨内出現に関し木村 (1933) は次の 如く述べている。即ら「正常な状態では， stabiles oder Funktionsglykogen として多くの扁平上皮に存 し，一般に急速に発宵する臓器に多量に存在し, 月脛直 前の子宫粘膜，心の刺㥂伝尊線䊒にもみられる。病的状
態として，循環障害・毒物による障害・伝染病・炎症等 に際して普通には sichtbares Glykogen 含まない好 中球・幼若結合織細胞・内皮細胞・上皮に発現する」と 述べている。島田（1933）は改良 Best 氏カルミン染色 法にて検查し、リンパ節の被膜・濁胞・血管壁飞少量な がらこれを認めている. 人扁桃のグリニーゲンについて 山本（1932）は，「上皮表層には多量に，梁筧には少量。

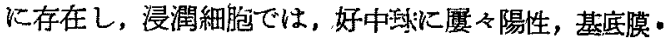

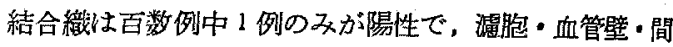

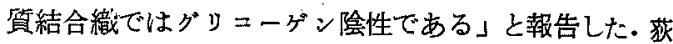
野（1941）は，Best 氏カルミン染色法を応用して検查 し，「扁桃の表面上皮には多量に，腺简上皮には中等度 に存在する. 炎症の急性捕们や小減少の㑯向がある. 基 底層・濾捾では少なく，間質結合織は最も少ない」と報 告した.今非 (1954)は，PAS 反応により，扁桃の上 这・血管壁・結合織力强陽性，濾胞侩性であるのを証 めた。また，消化試艅を行い，上汥では扁平細胞層，次 いで中層の扁平化せんとする細胞層がや】唾液消化を受 けるとして，山本・荻野の云う如く，人口蓋扁桃上皮に はグリニーグンを含むと考えた。板倉（1956）等は人咽 頭扁桃に PAS 反応を行い，線毛上皮上層は強く，潹

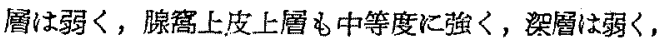

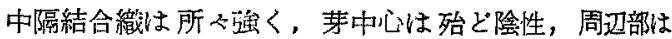
や〉強く，血管壁は强く染色される事を認めたが，ギ スターゼ消化試埈を行い，線毛上皮上㬝・血管等・上皮 下結合織で多少の染色性低下を示吉所もあるように思わ れるが，他部では何らの変化をる認めなかつたと述へて いる. 村上（1956）は PAS 染色で，芽中心・洉㴔共 に一般に弱染または陰性であるが，組織求槏細胞及び好 中冰に弱陽性をきたすむのがあり，消化試跧では殆と变 化を見なからたと報告した。

私の奏験では，PAS 染色で最も強く染るのは，被膜 及び中隔結合織・表面上在上層で，上皮深層は僅か沉染 り，腺謇上皮は表面上波に比して弱く染るが，角化上皮 队脱落上皮は相当好染し，また，芽中心は僅か儿染色さ れる.これらは経過日数により著明な增減は示さない。 しかし，消化試験を施した漂本と対比すればがシコー ゲン陽性（PAS 反応陰性）は，表 5 の如く上皮（特下

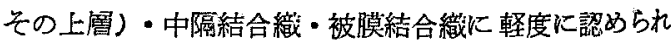
たが，高度な例はない。また瀘胞では全く認めていな い．経過日数との熨係を見ると，上皮組䋨では0〜2週 群で認めず，2〜3週群にや〉多量に認め，3〜8〜週磰 で少量に存在している。結合䢂成分では，間貿と被膜炕 
任よ同量認め，また，全群に軽度に存在している。しか し、さしろ0〜3週群が，3〜8〜週群より強い傾向があ z.

以上の私の成續と諸文献を検討すれば，PAS 陽性部 位们ついては全く一致する. 急性炎症症状消裉後の初期 には，荻野の述べた如く，上皮のグリニーゲン含有が軽 度に隇少する傾向すらから゙えたのであるが，結合䅧成分 では，後期に却つて減少するのではないかと判断され る成輤である.なお，村上の述べた溜胞で弱染する組織 辚样細胞は，芽中心で割に好染する賀哙細胞に相当する であらうと私は推定する。

\section{2. 粘夜に関して}

口蓋扁桃の近傍には，大・小口腔腺，鼻・咽頭・下気 道・消化器系の俆液腺・粘液腺が存在する・これらより 分谈される粘液には，消化䤃素，蛋白質，粘茅等が含ま れ，Best 氏为ルミ媣色法，Mayer 氏ムチカルミン染 色法，PAS 染色等で赤染されるまた，垂液中には，

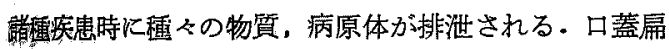
能炎に批いては口蓋腺，特にその導管が扁挑を貫き腺窝 几開口する粘液腺に変化が見られ，その機能にも影響が ある百のではないかと推定される。

私の検甞した 25 例中，上皮・結合織は約半数が弱染 し，その中，粘液腺を標本上認めた11 例では，いずれ れ粘液腺細胞・腺腔及び尊管内容物は強染したが，粘液 䠌の有無や，経過日数との関連性は特浔めなかつた。

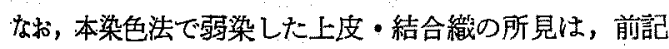
PAS 反応陽性部位と合致している所から, 扁桃の PAS 反院陽性物質には，粘液染色陽性物質も含むむのと結論 できる。

\section{3. アミロ 1 ぼ関して}

私の啮りようした本邦交献中には，扁挑のアミロイド 炕関する明膫な記載は見い出されなからたのであるが， 岡本・上田その他に上れば, 他䏩器のアミロイドについ ててかから多数の報告をみた。

私の検索では，60例中 4 例 (15\%) 飞部分的にアミロ イド変性を認めたが，いずれも軽度で，その認めた部位

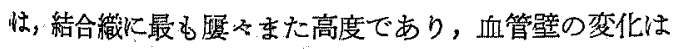
弱加た。結合䋨では, 脾の本变性と同様に細網線維に 沈着していた事は與味潹いが，リンパ節ではその湜胞の 唚される事多しとの記載があるが，私の材料では1例も 届桃爟胞には認められなかつた. 中隔結合織と接するり ンバ細胞带の細網線䊒が同変性を起している1例を認め たのみである. 木村の記載を引用すれば，私の見た 4 例
のアミロイド変性は, lokale Amyloiderkrankung に 属し, chronische Vereiterung (多くは Staphylokokken）により産生されたものと考えて差し支えないと思 う.この 4 例は，病歴その他で特に他症例と避ら゙所がな い.な招，2名は急性炎症症状消裉後極く初期の 0 1 週群に属し，他の 2 名は後斯の 8週〜群に属している:

4. 核酸に関して

扁桃の核酸について, 今井 $(1954,1955)$ は家乘扁桃 で研究し，一般には DNA が多く，RNA は少ないと 報告し，DNA は濾胞・リンパ球の遊出細胞，次いで上 皮細胞に認め，RNA は上皮細胞に認められ，濾胞・遊 出細胞にる存在すると思わ机ると述べている．同氏は人 咽頭・口蓋扁北を検索し，Feulgen 反応では，澏胞・ 尉中心・細網細胞・遊出細胞飞認女，上皮基底細胞・結 合織・血管壁にも軽度に認めている.更にテオニン及び ビロニン・メチール緑染色を行い，浸潤細胞や增殖盛ん な芽中心・周辺部には特に高重合の DNA 多く，退行 变性の認められる濾胞・血管壁には RNA を認めてい る. 板倉等は, 咽頭扁挑で，Mazia 等の $\mathrm{Hg}$. BPB 法を行い，今讲とほぶ同様の成續を得た。また，斎藤 (1954) 等は, 人扁桃の生訨学的細胞学的研究をなし, 炎症時の 扁桃では, Albumin は大体一定であるが， $\gamma$-Globulin・形質球の增加があると述べた。村上は， ビロニン・メテール緑染色と Feulgen 反応を行い，単 性肥大扁桃では，芽中心で sog. Lymphogonia (天野) と思われるるのにピロニン好性を見，炎性稨桃では， Lymphogonia の好染性は炎症に比例して增大寸ると述 ベている。また，単性肥大扁恌の濾胞部ではほら゙陰性， 炎性扁挑の濾胞周辺部でかなり強いピロニン好性細胞群 を認め，慢性炎では，形質球・組織球・分剖核・崩培 核・濃縮核・核崩壊物にピロニン好性を認めたとして， 単性肥大と炎性扁挑間のと゚ロニン好染性に差異を見い出 している.

私の成續では，各部位のピロニン陽性度は，今井・板 倉等とほよ゙同様であるが，経過日数とピロニン陽性度に ついて見れば，各群間に著明な差異は認め難く，また， 村上の述べならな炎症に比例する Lymphogonia の 好染性の增加は結論できない。

5. 脂質に関して

脂質の租織化学的研究は, 既に鴉木 (1927) が人扁桃 で行つている. 氏は，凍結切片で， S. III, ニニートラル

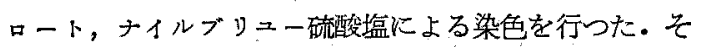
して遊走して現かれる脂肪滴無構造のもの及び間質の線 
維あるいは血管及び 神経線維に現れるものに 分けて述 へ，更に年令的には，年令と共に增加し，若年者では陰 性のものが多いと発表した。板倉等も人咽頭扁挑で，ぜ ラチン包埋，S.B.B. 染色を行い，線毛上皮上稞に脂肪 滴としてこれを認め，下層に行くに従つて弱く，また， 腺窝上皮は表面上皮上り弱く，荎中心はその周辺部上り 弱く，間質・結合織・血管壁も弱染する事を認妉た 村 上は，カーボワックス包埋， S.B.S. 染色を行つた・そ

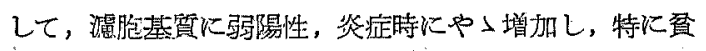
哙細胞に顆粒状並びに潮漫性に高度陽性の成漬を得た。

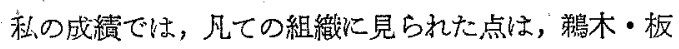
倉等と同じであるが，私の場合では，被膜部殊に扁挑門

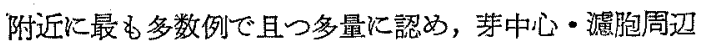
部に和いても少数例では高度陽性所見を得た・その他， 上皮・上皮下結合織では非常に弱く，認める場合も数少 ない，年階的には 15〜30 䪱に最も多く脂質增加の傾 向は諗めるが，若年者群でる約 $1 / 3$ はいずれかの部分に 脂質が見い出された. 各群別には，S.II， S.B.B. 耐染色 での陽性率は泀ぶ平行関係を見，著明な差異はないが， 前半には少なく，後半には多量になる傾问がみられる。 左右差は少ない，また，村上の上うに，炎症時に特に增 加すると云う所見は得られなからた。

6. 組織肥胖細胞に関して

組織肥㭌細胞の顆粒について,Holmgren・Wilander Jorpes (1937) は，ヘパリンが含まれていると述べ,こ れが具液㠜固性の調節之絬びつけられて考学られるよう になつた. 一方 Asboe-Hansen (1950) は，ヒアルロ 酸の産出を提唱してから結合織との関係が論議され， Morrione (1952) は，結合織特にその線維化機転の旺 盛な所には本細胞が常在するとしてから，実験的にも溶 性コラゲンにへパロンを加える事により，膠原線維形成 を見て括り，更に Riley (1953), Rocha, Silba (1952) は，本顆粒にヒスタミンが含まれる事を証明している。

耳鼻积領域での 本細胞の 研究は甚だ少ないのである が，下鼻甲介粘膜で石井 (1957) が，副鼻腔粘膜で井村 (1959) 等が上皮居に本細胞を認めたとしており，私む 扇桃上皮内にメタクロマジー陽性細胞を認めた・これに よつてこの細胞忙上皮内を遊走する可能性があると考兄 られる・また，扁桃に和ける本細胞の分布を考察する に，恰か子結合䋘に専ら関係があるかの如く，結合織成 分に最も多く発見でき，艺の他瀶胞周辺部等にも認めら れた・田島 (1958) の扁桃のスタンフ標本による成績で は，本細胞は平均して全細胞の $0,04 \%$ と算定され，急
性斯にや>減少 (0.03\%) する傾向を認めているが，全 般的には変動性の大きい数値を示しているよらである. 私も本細胞を，徱本上散発的济珰めたのであるか，数的 には 2 週〜群に多数見られた・しかし，全く認めない例 もある.一方，白鳥（1959）は虫垂に打㚈本紐胞の消 長を研究し，急性炎時注淡症野減少し，周辺江增 加し，慢性炎には增加の傾向を認めている.これから推

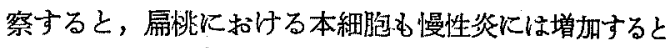
見てょいであろう。

\section{7. 組 織 鉄}

私の観察した扁桃の組織銑は，へモジデリンと思考さ れるが，湢胞周辺部に比較的多く諗められた。しかし，

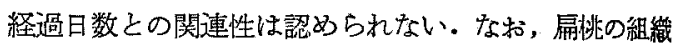
鉄に関して特に研究した報告は見当らなかつた。

\section{第 $\mathbf{V}$ 章 結 論}

私は人口蓋扁桃の急性炎症症状消裉後（以下経過日数 之記す)に拉ける物質代謝を組織!比学的に研究する事を

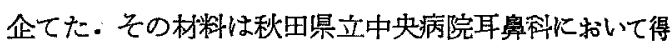
た60例（113個）で，経過日数は 8 週以上K及ぶもの ある.検查して得た成續は次の如くである。

1) PAS 陽性物質は被膜結合繶・中隔結合織・表面 上皮の表層に多く，上皮梁層・腺譪上皮には少ない。茅 中心には僅かにみられる・経過日数との関係をるると， 著明な增減傾向は認められない。消化試験を行つで゚リ コーグン含有状態を推察すると，被膜結合織・中隔結合 織・上皮表層に軽度に認められたが，リンバ濾胞には㒛 められなからた・経過日数を考虑してみると，上皮組樴 では初期にはなく，中期にや〉增加し，後期汇減少才 る.結合織では前半が後半より多い傾向がある.

2) 粘液染色炕よる陽性度之経過日数の間には特記す る程の変化傾向は認められなかつた。

3） 4 例に 部分的アミロイド変性を認めた．2 例は前 期，2例は後期のものであつた・その出現部は中隔結合 織が主であつて，リンバ濾胞には殆ど認められなかつ た。このアミロイド变性は慢性化膿性炎の結果と思われ る.

4）ピロニン好性物質は上文細胞に多く，泿胞内・遊 走細胞・血管壁・結合織にる軽度に認ぬられる・経過日 数とこの物質との間には特記すべき関係は見出し得なか つた・たぶし陽性遊走細胞は後期に多かつた。 Lymphogonia (天野) の好染性の增減を暗示させるような所 見には接しなかつた。

5）脂質は総ての組織に見られたが，ズダン』好性の 
滴としては被膜に多く，時には茅中心や媳胞周边部にる 見られた・上皮には少ない。また脂質は16〜30才頇に 多い. 経過日数との関係をみると，出現頻度には余り差 がない゙後半にはやつ多量になる傾向が見られた・

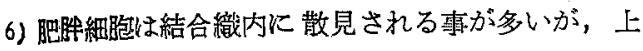
皮内に見られるので，その遊走性が考えられる。 た，慢性炎の場合は一般に增加の傾向を示寸。

7)へモジデリンの沈着は、リンパ澤胞結合織・上皮 維織に散見されたが，や〉㴔胞に頻発の傾向がある・経 過日数からみて，特記すべき傾向は見い出し得なかつ た.

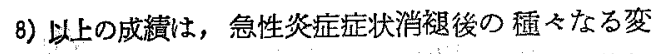

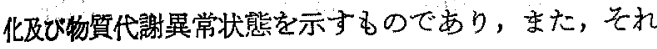
らの一部は相当長期間残存する事を示す.

\section{主要文献}

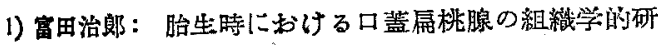

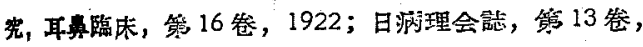

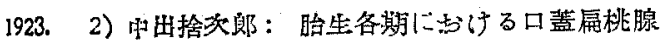

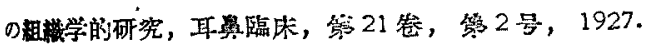
3) 鶇太秀三：口蓋雇桃の源理租織学的研究，殊に人口

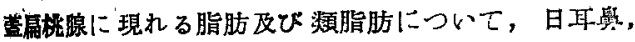
第33卷, 第 $7 \sim 9$ 量, 1927. 4) W. von Möllerdorff: $\mathrm{Ph}$. Stöhrs Lehrbuch der Histologie, 22 Auflage,

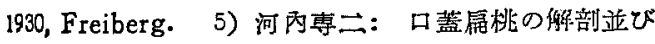
に病理蛆織学的補遒，京府医大誌，管; 5 卷，第 1 号， p. 101，1931，6）林利男也：小满理学䋓論, 中卷, 1933, 東京 (金原商店). 7) 松谷展造：日䔔扁㭠腺

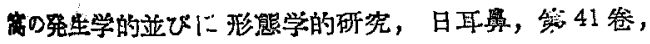

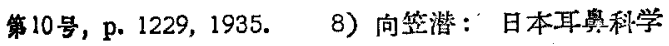
全書, 第7 替の 1,1939 ，東京 (克諴堂)。9）袖谷雄

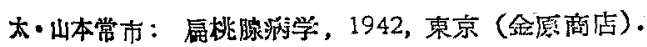

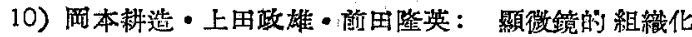
学, 1050, 東京 (医学書院). 11) Morrione, T.G.: The formation of collagene fibers by the action of heparin on soluble collagen: an electoron microscope study, J. exp. Med. 96, 2, p. 107, 1952. 12)

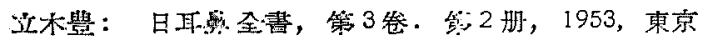

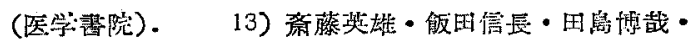

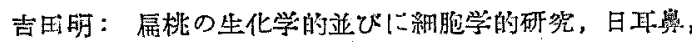

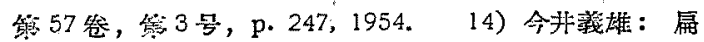

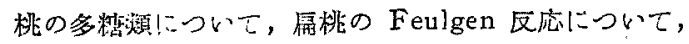
四国医誌，5６，p.75，1954. (18) 」り引用). 15)

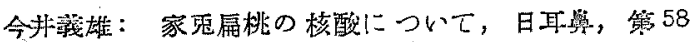

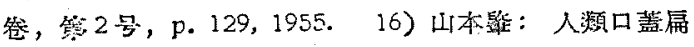

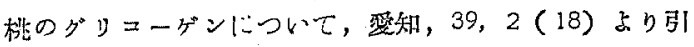
用).17）荻野孝之：人体口蓋瀜桃の粕原の租織学的

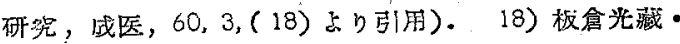

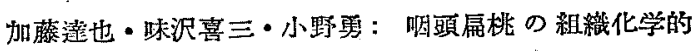

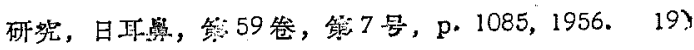

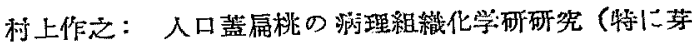

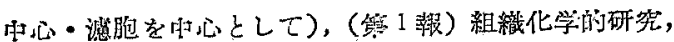

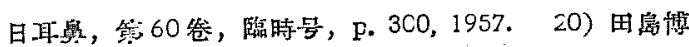

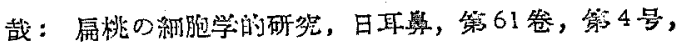

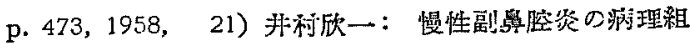

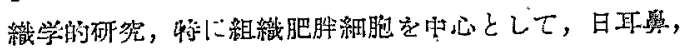

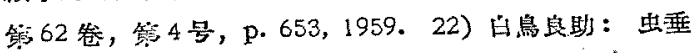

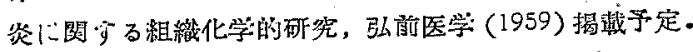

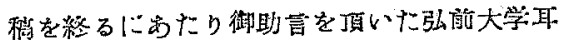

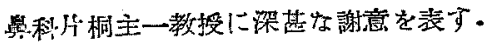

（厚稿到盖二昭利 34.8 .27 日） 